\title{
SEROTONIN LEVEL IN PERIPHERAL BLOOD AND THE BRAIN'S BIOELECTRICAL ACTIVITY IN YOUNG PEOPLE 15-17 YEARS
}

\author{
E.V. Krivonogova, L.V. Poskotinova, D.B. Demin, O.A. Stavinskaya
}

N. Laverov Federal Center for Integrated Arctic Research, RAS, Arkhangelsk, Russia

\section{УРОВЕНЬ СЕРОТОНИНА В ПЕРИФЕРИЧЕСКОЙ КРОВИ И БИОЭЛЕКТРИЧЕСКАЯ АКТИВНОСТЬ ГОЛОВНОГО МОЗГА У МОЛОДЫХ ЛЮДЕЙ 15-17 ЛЕТ}

\author{
Е.В. Кривоногова, Л.В. Поскотинова, Д.Б. Дёмин, О.А. Ставинская \\ ФГБУН «Федеральный исследовательский центр комплексного изучения Арктики \\ им. акад. Н.П. Лавёрова РАН», Архангельск
}

\begin{abstract}
The purpose of the work is to evaluate the features of the organization of the bioelectrical activity of the brain with different levels of serotonin in the serum of peripheral blood in young people 15-17 years old. The study involved 93 healthy girls and boys (15-17 years) of the Arkhangelsk region and the Nenets autonomous okrug. A serotonin level is determined in serum by enzyme immunoassay using a set of "Serotonin ELISA". The electroencephalogram (EEG) power spectrum (PS) in the alpha, beta and theta frequencies ranges was recorded using an electroencephalograph "Encephalan" (Medicom, Taganrog). Age-dependent electroencephalogram (EEG) patterns is associated with the level of serotonin in peripheral blood in adolescents. On the background of a higher level of serotonin in the blood, compared to girls, boys have localized associations of theta and betal activity of EEG and serotonin levels, mainly in the right frontal-temporal region. In girls, the spectral power level of the EEG theta activity is more dependent on the level of serotonin in the blood, and a greater number of brain areas are involved in correlation interactions in comparison with young men (temporal regions on the left and frontal, central, parietal regions of both hemispheres of the brain).
\end{abstract}

Keywords: serotonin; EEG; adolescents.

Цель работы - оценить особенности организации биоэлектрической активности головного мозга с различным уровнем серотонина в сыворотке периферической крови у молодых людей 15-17 лет. Обследовано 93 практически здоровых молодых людей Архангельской области и Ненецкого автономного округа. Уровень серотонина определяли в сыворотке крови методом иммуноферментного анализа набором «Serotonin ELISA». Электроэнцефалограмму (ЭЭГ) регистрировали по 16 каналам с помощью электроэнцефалографа («Энцефалан-131-03», «МЕДИКОМ МТД»). В период возрастного становления ритмозадающих структур головного мозга степень сформированности ЭЭГ-паттернов ассоциирована с уровнем серотонина в периферической крови у подростков. У юношей на фоне более высокого уровня серотонина в крови в сравнении с девушками наблюдаются локализованные ассоциации мощности тета- и бета1- активности ЭЭГ и уровня серотонина, преимущественно в правой лобно-височной области. У девушек активность ритмозадающих структур головного тета-диапазона ЭЭГ в большей степени зависит от уровня серотонина в крови, а в корреляционные взаимодействия вовлечено большее число областей мозга в сравнении с юношами (височные отделы слева и лобные, центральные, теменные области обоих полушарий головного мозга).

Ключевые слова: серотонин; ЭЭГ; подростки.

Introduction. Studying the characteristics of the organization of the bioelectrical activity of the brain depending on the serotonin level in the blood serum can clarify the role of electroencephalography (EEG) as a method for diagnosing neurological disorders associated with impaired neurotransmitter metabolism at different age stages. The purpose of the work is to evaluate the features of the organization of the bioelectrical activity of the brain with different levels of serotonin in the serum of peripheral blood in young people 15-17 years.

Materials and methods. The study involved 93 healthy girls and boys (15-17 years) of the
Arkhangelsk region and the Nenets autonomous okrug. Research was conducted with ethical standards. A serotonin level is determined in serum by enzyme immunoassay using a set of "Serotonin ELISA" (Germany) by Lyutfaliyeva G.T. and Stavinskaya O.A. Normative values of serotonin level reached for girls are $80-450 \mathrm{ng} / \mathrm{ml}$, for boys $40-400 \mathrm{ng} / \mathrm{ml}$. The EEG power spectrum (PS) in the alpha-, beta1- and theta- frequencies ranges was recorded using an electroencephalograph "Encephalan" (Medicom, Taganrog). Statistical processing of materials was performed in the program Statistica. Parameters characterized by a median and 25,75 percentiles. The significance of the 
differences between the two independent groups was determined using the Mann-Whitney method. Correlation analysis was performed by Spearman at a significance level of $p<0.05$.

Results and discussion. The serotonin level in the peripheral blood of girls was 146.7 [81.6; 271.2] $\mathrm{ng} / \mathrm{ml}$ with a range of values from 42.1 to $581.3 \mathrm{ng} / \mathrm{ml}$ (min-max), which is significantly lower than that of boys $241,9[94.5 ; 374.5] \mathrm{ng} / \mathrm{ml}(p=0.03)$ with a range of values from 45.3 to $604.3 \mathrm{ng} / \mathrm{ml}$. In girls, in $22 \%$ of cases, serotonin levels were lower than reference values $(<80 \mathrm{ng} / \mathrm{ml})$. Young people living in the Nenets Autonomous District more often recorded serotonin levels above the reference values [1]. In boys, the SP in the beta-1 EEG range is statistically lower than in girls, which is probably related to the later development of the corticalhippocampal system and certain cortical structures involved in the generation of high-frequency EEG activity. Analysis of the SP of the EEG showed that in girls with low serotonin levels the spectral power of the theta activity in F7 and T3 $(p<0.05)$ was lower compared to girls with normal serotonin levels. According to a correlation analysis, the associations of cortical brain activity and serotonin levels in the blood were more localized in boys compared with girls. So, in boys, correlations were found between the level of serotonin and betal-activity of EEG in the frontal region (F4, $(r=0.34, p=0.03)$, $\mathrm{Fp} 2,(r=0.40, p=0.01))$ and the temporal region of the brain on the right $(\mathrm{F} 8, r=0.39, p=0.02)$. Correlations between the serotonin level and the SP of the EEG theta-activity were also single - in C4 $(r=0.32, p=0.04)$, in F8 $(r=0.43, p=0.006)$. In girls, on the contrary, the positive correlations between the serotonin level and the SP in the theta EEG range were extensive - in the frontal $(\mathrm{F} 4$, $r=0.29, p=0.007, \mathrm{~F} 3, r=0.24, p=0.03)$, central $(\mathrm{C} 4, r=0.23, p=0.03, \mathrm{C} 3, r=0.27, p=0.01)$, parietal $(\mathrm{P} 4, r=0.22, p=0.04, \mathrm{P} 3, r=0.30$, $p=0.004)$ areas of the brain and temporal regions on the left (T5, $r=0.28, p=0.007$, T3, $r=0.37$, $p=0.0005, \mathrm{~F} 7, r=0.35, p=0.0001)$. In studies by observing the effects of the drug (serotonin), applied topically at the site of the area postrema in cats, it was found that serotonin increases the low-frequency components and reduces the highfrequency components in the cortical EEG [3]. An increase in serotonin level in bioacoustic correction sessions is accompanied by an increase in the theta activity index of the left occipital lead [2]. High levels of serotonin in the peripheral blood of women may be associated with impaired agerelated formation of amplitude-frequency EEG patterns, when there is a pronounced slow-wave EEG activity, especially with paroxysmal phenomena. That is, the pronounced theta activity of EEG, especially in the frontal, parietal and central areas of the brain in combination with a high level of serotonin in the blood, can be considered as an indicator of diencephalic dysfunction in adolescents due to impaired serotonin metabolism. Agedependent EEG patterns is associated with the level of serotonin in peripheral blood in adolescents. On the background of a higher level of serotonin in the blood in comparison with girls, boys have localized associations of theta and beta1 potency of EEG activity and serotonin level, mainly in the right frontal-temporal region. In girls, the activity of structures producing rhythms of the head theta range of the EEG largely depends on the level of serotonin in the blood, and a greater number of brain regions are involved in the correlation interactions in comparison with young men (temporal regions on the left and frontal, central, parietal regions of both hemispheres of the brain).

Acknowledge. The work was performed according to the fundamental research work of N. Laverov Federal Center for Integrated Arctic Research, RAS (No. of state registration 115050610141).

\section{References}

1. Krivonogova EV, Poskotinova LV, Demin DB, Stavinskaya OA. A biofeedback by HRV-parametres and serotonin levels in young people of the Nenets Autonomous district and Arkhangelsk area. Fundamental research. 2012;11(1):25-29.

2. Konstantinov KV, Karpenko MN, Leonova MK. Dynamics of serotonin level in the sessions of listening to acoustic image of patient's own EEG. Neurocomputers. 2014;7:32-36.

3. Bronzino JD, Brusseau J, Morgane PJ, Stern WC. Power spectrum analysis of EEG synchronization following application of serotonin to area postrema. Annals of Biomedical Engineering. 1972;1:246-253. 